\title{
Molecular and immunological characterization of Hyalomma dromedarii and Hyalomma excavatum (Acari: Ixodidae) vectors of $Q$ fever in camels
}

\author{
Hend H. A. M. Abdullah, Eman E. El-Shanawany, Sobhy Abdel-Shafy, Hala A. A. Abou-Zeina and Eman H. Abdel-Rahman \\ Department of Parasitology and Animal Diseases, Veterinary Research Division, National Research Centre, Dokki, \\ Giza, Egypt. \\ Corresponding author: Sobhy Abdel-Shafy, e-mail: aasobhy@yahoo.com \\ Co-authors: HHAMA: vet_nrc_2006@yahoo.com,EEE: ee.elshanawany@hotmail.com, \\ HAAA: hala_zeina60@yahoo.com, EHA: emanhussein1@hotmail.com \\ Received: 01-06-2018, Accepted: 05-07-2018, Published online: 12-08-2018
}

doi: 10.14202/vetworld.2018.1109-1119 How to cite this article: Abdullah HHAM, El-Shanawany EE, Abdel-Shafy S, Abou-Zeina HAA, Abdel-Rahman EH (2018) Molecular and immunological characterization of Hyalomma dromedarii and Hyalomma excavatum (Acari: Ixodidae) vectors of Q fever in camels, Veterinary World, 11(8):1109-1119.

\begin{abstract}
Background and Aim: Q fever Coxiella burnetii is a worldwide zoonotic disease, and C. burnetii was detected in mammals and ticks. Ticks play an important role in the spread of $C$. burnetii in the environment. Therefore, the aims of this study were to detect Q fever C. burnetii in camels and ixodid ticks by molecular tools and identification of Hyalomma dromedarii and Hyalomma excavatum using molecular and immunological assays.
\end{abstract}

Materials and Methods: A total of 113 blood samples from camels and 190 adult ticks were investigated for the infection with $C$. burnetii by polymerase chain reaction (PCR) and sequencing the targeting IS30A spacer. The two tick species $H$. dromedarii and $H$. excavatum were characterized molecularly by PCR and sequencing of $16 \mathrm{~S}$ ribosomal RNA (16S rRNA) and cytochrome oxidase subunit-1 (CO1) genes and immunologically by sodium dodecyl sulfate-polyacrylamide gel electrophoresis (SDS-PAGE) and western blot.

Results: A total of 52 camels (46\%) were positive for Q fever infection. Only 10 adult ticks of $H$. dromedarii were infected with $C$. burnetii. The IS30A sequence was around $200 \mathrm{bp}$ in length for $C$. burnetii in $H$. dromedarii ticks with a similarity of $99 \%$ when compared with reference data in GenBank records. The length of 16S rDNA and CO1 was 440 and 850 bp, respectively, for both $H$. dromedarii and $H$. excavatum. The phylogenetic status of $H$. dromedarii was distant from that of H. excavatum. SDS-PAGE revealed seven different bands in the adult antigens of either $H$. dromedarii or $H$. excavatum with molecular weights ranged from 132.9 to $17.7 \mathrm{KDa}$. In western blot analyses, the sera obtained from either infested camel by $H$. dromedarii or infested cattle by $H$. excavatum recognized four immunogenic bands $(100.7,49.7,43.9$, and $39.6 \mathrm{kDa})$ in $H$. dromedarii antigen. However, the infested camel sera identified two immunogenic bands $(117$ and $61.4 \mathrm{kDa})$ in $H$. excavatum antigen. Furthermore, the sera collected from cattle infested by $H$. excavatum recognized three immunogenic bands $(61.4,47.3$, and $35 \mathrm{kDa})$ in $H$. excavatum antigen.

Conclusion: Molecular analyses indicated that both camels and ticks could be sources for infection of animals and humans with Q fever. Furthermore, the molecular analyses are more accurate tools for discriminating H. dromedarii and H. excavatum than immunological tools.

Keywords: 16S ribosomal DNA, Coxiella burnetii, cytochrome oxidase subunit-1, hard ticks, phylogeny, polymerase chain reaction, sequence, sodium dodecyl sulfate-polyacrylamide gel electrophoresis, western blot.

\section{Introduction}

Q fever is a worldwide zoonotic disease caused by an obligate Gram-negative bacterium Coxiella burnetii [1]. In 1935, the first identified outbreak of the disease happened among Austrian abattoir workers [2]. Domestic animals such as cattle, sheep, and goats are known reservoirs of $C$. burnetii [3]. Antibodies to $\mathrm{Q}$ fever were detected in camels without any clinical signs $[4,5]$. The infection in animals is usually subclinical, but abortion and reduction in reproductive efficiency are the most critical

Copyright: Abdullah, et al. Open Access. This article is distributed under the terms of the Creative Commons Attribution 4.0 International License (http://creativecommons.org/licenses/ by/4.0/), which permits unrestricted use, distribution, and reproduction in any medium, provided you give appropriate credit to the original author(s) and the source, provide a link to the Creative Commons license, and indicate if changes were made. The Creative Commons Public Domain Dedication waiver (http:// creativecommons.org/publicdomain/zero/1.0/) applies to the data made available in this article, unless otherwise stated. investigation of such disease [6]. In human, the disease causes acute flu-like illness, hepatitis, pneumonia, and chronic endocarditis [7,8]. Recently, the genus Coxiella is closely related to the order Legionellales (Gammaproteobacteria) [9]. C. burnetii and Coxiella cheraxi (a pathogen of crayfishes [10]) are the only identified pathogens in such genus. Moreover, many Coxiella-like organisms were detected in the invertebrate species, especially ticks $[11,12]$, depending on 16S rRNA gene sequencing as a universal DNA barcoding marker [13]. These organisms were closely related to C. burnetii but genetically distinct [14]. In addition, many of $C$. burnetii were isolated from animals and human during $Q$ fever outbreaks [15-17] and in more than 40 tick species in different countries [18]. It multiplies in the tick-middle gut, resulting in high numbers of viable organisms that are excreted with feces, saliva, and coxal fluid. Ticks can transmit C. burnetii transstadially and transovarially to their 
offspring [19]. Ticks play an important role in the spread of $C$. burnetii in the environment, especially wildlife, because of the high concentration of this bacteria in tick feces $[20,21]$.

The camel tick Hyalomma dromedarii Koch, 1844 (Acari: Ixodidae), prefers the camel as the primary host of the adult stage. It also infests other domestic animals such as cattle, sheep, goats, and equines. Larvae and nymphs feed on birds and small burrowing animals as rodents, but the nymphs can infest large animals like the adults. It commonly behaves as a two-host tick and appears throughout the year. It is found wherever camels live and it distributes mainly in North Africa, Mauritania, Middle East, India, Mongolia, Tibet, Ethiopia, Eretria, Kenya, and Uganda [22,23]. It is the most Hyalomma spp. parasitizing camels in Egypt [24-26]. It has a vital role in the transmission of emerging and reemerging diseases as Theileria [27,28], Rickettsia [29,30], Francisella [31], Q fever [32], and viruses [33].

The tick Hyalomma excavatum Koch, 1844 (Acari: Ixodidae), has a wide range of animal hosts as cattle, camels, equines, sheep, goats, and dogs and it can attack humans. It feeds as a two-host or three-host tick according to the availability of hosts. Larvae and nymphs feed on small vertebrates, birds, and human. It is found throughout the year with a reduced number in winter [34,35]. It is distributed mainly in North Africa including Egypt, Sudan, Ethiopia, Eritrea, Iran, Turkey, Italy, and Greece [36]. Furthermore, H. excavatum plays a role in the transmission of protozoan diseases as babesiosis and theileriosis [37-39], bacterial diseases as rickettsiosis [30], and viral diseases as Crimean Congo hemorrhagic fever [40].

Moreover, the identification of ticks depends on the morphological characteristics of the adult stages that are easily observed by light microscope. It is difficult to identify the ticks depending on the morphological features in three cases. The first case is the female that is laying eggs because the structure of its genital opening is not clear enough to distinguish the tick species. The second case is the damaged ticks, especially important taxonomic parts, such as mouthparts, scutum, and genital opening. The third case is the immature stages which need more advanced tools to identify ticks at the species level [41,42]. Scanning electron microscope was used to describe the immature stages of $H$. dromedarii, H. excavatum, and Hyalomma marginatum [43]. He found that the nymphal stage was well differentiated between the three species, while the larval stage of each $H$. dromedarii and $H$. excavatum is very close to each other. This finding led to a search for other tools to confirm the identification of ticks in such case.

In Egypt, there is not enough available data about $\mathrm{Q}$ fever in camels linked with their tick vectors. Therefore, the aims of this study were to detect Q fever C. burnetii in camels and ixodid ticks using PCR and sequencing of the targeting IS30A spacer and to evaluate 16S ribosomal RNA (16S rRNA) and cytochrome oxidase subunit-1 (COI) genes using PCR and sequencing as molecular methods and sodium dodecyl sulfate-polyacrylamide gel electrophoresis (SDS-PAGE) and western blot as immunological methods for characterization of the two tick species $H$. dromedarii and $H$. excavatum.

\section{Materials and Methods}

\section{Ethical approval}

This study was approved to be carried out by the Ethics Committee at the National Research Centre in Egypt.

\section{Animals}

A total of 113 camels were examined for the presence of ticks on different parts of their bodies according to Abdullah et al. [25] from Cairo, Giza, and Sinai in Egypt during the period from June to August 2017. Blood samples with ethylenediaminetetraacetic acid (EDTA) (5 ml each animal) were collected from jugular veins and were stored at $-20^{\circ} \mathrm{C}$ for molecular purposes.

\section{Ticks}

A total of 268 ticks were collected from camels from Cairo, Giza, and Sinai in Egypt during the period mentioned above. Ticks were removed from camels using curved forceps into plastic tubes. Then, the tubes were covered with cloths and secured by rubber bands. Ticks were brought alive to the laboratory for further identification and investigation. The adult ticks were identified by the key of Estrada-Pena et al. [36]. Then, the ticks were stored at $-20^{\circ} \mathrm{C}$ until DNA was extracted for molecular procedures. $H$. dromedarii and $H$. excavatum were chosen for the molecular and immunological investigations.

\section{Molecular techniques}

\section{DNA extraction}

DNA was extracted from blood using GF-1 Tissue Blood Combi DNA Extraction Kit (SNF, Vivantis, Malaysia) according to the manufacturer's instructions. Furthermore, DNA was extracted and purified from adult ticks individually after dissection a tick into two halves. The high salt concentration protocol was used for DNA extraction [44]. The NanoDrop 2000c (Thermo Scientific) was used for the measurement of the purity and concentration of DNA that was stored at $-20^{\circ} \mathrm{C}$ until used in PCR procedures.

\section{PCR protocol}

The primers used in this study are presented in Table-1 $[21,45,46]$. The PCR reaction was performed in $25 \mu \mathrm{l}$ total volume under aseptic condition. Each PCR mixture contained $25-50 \mathrm{ng} / \mu 1$ genomic DNA, $10 \mathrm{pM} / \mu 1$ of each primer, $12.5 \mu 1$ of $2 \times$ PCR Master Mix solution (i-Taq) PCR master mix (1× buffer, $2.5 \mathrm{mM}$ dNTP, $1 \times$ gel loading buffer, and $4 \mathrm{mM} \mathrm{MgCl}$; iNtRon Biotechnology, Korea), and $9 \mu 1$ nuclease-free water (Qiagen) to complete the total volume of the 
Table-1: Primers utilized in PCR amplification and sequencing of genes.

\begin{tabular}{|c|c|c|c|}
\hline DNA marker & 5'- Primers Sequences-3' & Amplified fragments & References \\
\hline $\begin{array}{l}\text { IS30A } \\
\text { IS30A-F } \\
\text { IS30A-R }\end{array}$ & $\begin{array}{l}\text { 5'-CGCTGACCTACAGAAATATGTCC-3' } \\
\text { 5'-GGGGTAAGTAAATAATACCTTCTGG-3' }\end{array}$ & $196-166$ bp & [21] \\
\hline $\begin{array}{l}\text { CO1 } \\
\text { CO1-F } \\
\text { CO1-R }\end{array}$ & $\begin{array}{l}\text { 5'-GGAACAATATATTTAATITITGG-3' } \\
\text { 5'-ATCTATCCCTACTGTAAATATATG-3' }\end{array}$ & $732-820 \mathrm{bp}$ & [45] \\
\hline $\begin{array}{l}16 \mathrm{~S} \text { rDNA } \\
16 \mathrm{~S}-\mathrm{F} \\
16 \mathrm{~S}-\mathrm{R}\end{array}$ & $\begin{array}{l}\text { 5'-TTAAATTGCTGTRGTATT-3' } \\
\text { 5'-CCGGTCTGAACTCASAWC-3' }\end{array}$ & 455 bp & [46] \\
\hline
\end{tabular}

CO1=Cytochrome oxidase subunit-1

reaction. All amplifications were performed in BIORAD Thermal Cycler (BIO-RAD, Singapore) utilizing the following cycling profile, for the two DNA markers one cycle at $94^{\circ} \mathrm{C}$ for $5 \mathrm{~min}$ (initial denaturation). The PCR protocol of $\mathrm{CO}$ and $16 \mathrm{~S}$ rRNA genes was amplified 35 cycles of denaturation at $94^{\circ} \mathrm{C}$ for $1 \mathrm{~min}$, annealing at $45^{\circ} \mathrm{C}$ for $30 \mathrm{~s}$ and elongation at $72^{\circ} \mathrm{C}$ for $1 \mathrm{~min}$, and the final elongation at $72^{\circ} \mathrm{C}$ for $10 \mathrm{~min}[45,46]$. While, the IS30A protocol included 40 cycles of denaturation at $94^{\circ} \mathrm{C}$ for $30 \mathrm{~s}$, annealing at $52^{\circ} \mathrm{C}$ for $30 \mathrm{~s}$ and elongation at $72^{\circ} \mathrm{C}$ for $1 \mathrm{~min}$, and then the final elongation at $72^{\circ} \mathrm{C}$ for 5 min [21]. A reagent blank was run as control simultaneously with every PCR. The PCR products were inspected by electrophoresis in $1.5 \%$ agarose gel in tris-borateEDTA (TBE) buffer (45 mM TBE, $1 \mathrm{mM}$ EDTA, $\mathrm{pH}$ 8.3, Sigma-Aldrich) and stained with ethidium bromide (Sigma-Aldrich). A gene ruler 100 bp plus DNA ladder (Thermo Scientific, California, USA) was used with each gel. Gel photos were analyzed by Lab Image software (BioRad) [29].

\section{Sequencing of the $P C R$ products}

PCR products were purified for sequencing using ExoSAP-IT PCR Product Cleanup Kit (Affymetrix, Ohio, USA) according to manufacturer's recommendation. Sequencing reactions were performed in an MJ Research PTC-225 Peltier Thermal Cycler using an ABI PRISM ${ }^{\circledR}$ BigDye $^{\mathrm{TM}}$ terminator cycle sequencing kits with AmpliTaq ${ }^{\circledR}$ DNA polymerase (FS enzyme; Applied Biosystems), following the protocols supplied by the manufacturer.

\section{Phylogenetic analyses and tree construction}

Amplified sequences of each fragment were aligned using Blastn program of NCBI (http://www. ncbi.nlm.nih.gov/BLAST/) for sequence homology searches against GenBank database. Multiple sequence alignments for evolutionary relationships between obtained sequences and another reference in GenBank were inferred using the ClustalW $1.8^{\circledR}$ program [47], after modification of sequence length by BioEdit sequence alignment editor (v. 7.0.9.0). Two phylogenetic trees were constructed with the neighbor-joining method [48] and the unweighted pair group method with arithmetic mean (UPGMA) [49]. The evolutionary distances were calculated by the maximum composite likelihood method [50]. Branches corresponding to partitions reproduced in $<50 \%$ of bootstrap replicates were collapsed. Percentage of replicate trees in which the associated taxa clustered together in the bootstrap test (500 replicates) is shown next to the branches [51,52]. Phylogenetic analyses were conducted in MEGA4 [53].

\section{Immunological techniques}

\section{Antigen preparation}

Extraction of antigens was done in an ice bath. Adult female ticks of $H$. dromedarii and $H$. excavatum were triturated in a sterile glass mortar with $0.15 \mathrm{~mol} / \mathrm{L}$ PBS ( $\mathrm{pH}$ 7.2). The homogenate was sonicated and centrifuged at $13,000 \mathrm{rpm}$ for $1 \mathrm{~h}$ in a cooling centrifuge. The supernatant crude antigen was aliquot then preserved at -20 until used. The protein concentration of extract was estimated by the method of Lowry et al. [54].

\section{$S D S-P A G E$}

About $30 \mu \mathrm{g}$ of $H$. dromedarii or $H$. excavatum adult crude antigen was mixed with reducing sample buffer and loaded separately in 10\% SDS-PAGE [55]. Gels were silver stained according to the method of Wray et al. [56]. Molecular weight prestained protein ladder (Fermentas) ranged from 10 to $260 \mathrm{kDa}$ was electrophoresed in the same gel for comparative purposes.

\section{Western blotting}

Preparation of buffers, samples, and the transfer procedure was carried out according to the method described by Towbin et al. [57]. The resolved proteins were transferred to $0.2 \mu \mathrm{m}$ nitrocellulose membranes (Sigma, USA). Membranes were subsequently blocked with $5 \%$ skimmed milk in Tris-buffered saline with Tween ${ }^{\circledR} 20$ (TBST) buffer consisting of Tris, $125 \mathrm{mM}$ $\mathrm{NaCl}$, and $0.1 \%$ Tween 20 for $1 \mathrm{~h}$ at room temperature followed by incubation with primary antibodies (camel naturally infested by $H$. dromedarii and cattle naturally infested by $H$. excavatum) diluted at 1:100 in $0.01 \mathrm{M}$ Tris-buffered saline, $\mathrm{pH} 7.5$, containing $0.5 \%$ bovine serum albumin, overnight at $4^{\circ} \mathrm{C}$. Excess antibodies were removed by extensive washing in TBST, and blots were then reprobed with horseradish peroxidase (HRP)-conjugated protein A 1/2,000 dilution 
(Sigma, USA). Membranes were then washed extensively with TBST, and primary antibody binding was visualized with 4-chloro-1-naphthol as a substrate.

\section{Results}

\section{Molecular detection of $\mathbf{Q}$ fever}

A total of 113 blood samples from camels and 190 adult ticks were investigated for the infection with $C$. burnetii by PCR using IS30A spacer. The overall prevalence of Q fever in camels was $46 \%$, including $36(67 \%)$ and $16(27.1 \%)$ from Cairo and Giza, respectively. Only 10 adult ticks of $H$. dromedarii were infected with $C$. burnetii. The infected ticks were found at Giza Governorate and represented $5.3 \%$ of the total ticks (Table-2). The obtained IS30A sequence was around $200 \mathrm{bp}$ in length for C. burnetii in $H$. dromedarii ticks with a similarity of $99 \%$ when compared with other records of $C$. burnetii in GenBank (Figures-1 and 2).

\section{Molecular characterization of tick species}

The partial 16S rRNA gene revealed band around $440 \mathrm{bp}$ in length for both $H$. dromedarii and H. excavatum (Figure-3a). The band around $850 \mathrm{bp}$ in length was appeared with partial $\mathrm{CO1}$ gene for the two Hyalomma species (Figure-3b). The similarity of $H$. dromedarii for the obtained 16S rDNA sequence to the same tick species recorded in Genbank was $99 \%$, while the PCR product of $H$. excavatum $16 \mathrm{~S}$ rRNA gene failed to produce a good sequence. The

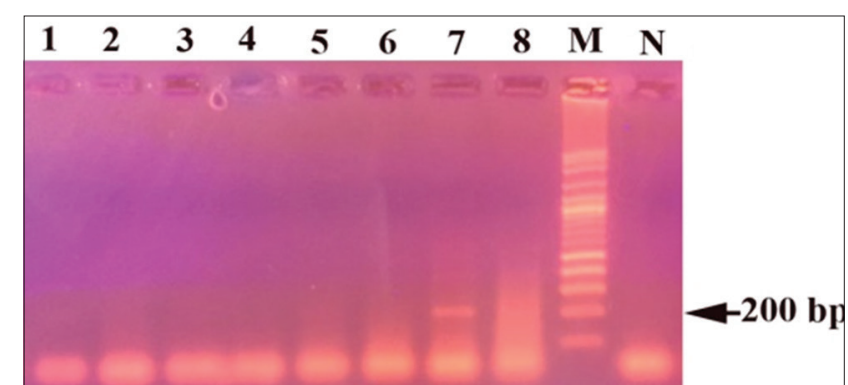

Figure-1: Agarose gel electrophoresis of polymerase chain reaction products obtained from $\mathrm{H}$. dromedarii using IS30A spacer: (M) 1 kb DNA ladder, (N) negative control, lanes 7 and 8 represent positive tick samples and lanes 1-6 represent negative tick samples. phylogenetic trees of $16 \mathrm{~S}$ rRNA and $\mathrm{COl}$ genes for $H$. dromedarii confirmed that these species locate in the same glade with others $H$. dromedarii recorded in GenBank (Figures-4 and 5). The phylogenetic tree of $\mathrm{COl}$ gene for $\mathrm{H}$. excavatum was also in a separate glade with others $H$. excavatum previously recorded in GenBank (Figure-5).

\section{Immunological characterization}

SDS-PAGE and silver staining analysis indicate unique protein profiles for each crude tick species (H. dromedarii and H. excavatum). The electrophoretic pattern of crude $H$. dormedarii adult antigen was released seven bands of different molecular weights $132.9,100.7,74,49.7,43.9,39.6$, and $17.7 \mathrm{kDa}$, while the $H$. excavatum crude adult antigen resolved seven bands differ from those of $H$. dromedarii, wherever they were 117.0, 61.4, 52.1, 47.3, 35, 29, and $18.9 \mathrm{kDa}$ (Figure-6).

The reactivity of naturally infested camel sera against the whole $H$. dromedarii adult tick was determined through four major protein bands with molecular weight $100.7,49.7,43.9$, and $39.6 \mathrm{kDa}$, while the reactivity of it with cattle sera naturally infested by $H$. excavatum was at $100.7,74,49.7$, and $43.9 \mathrm{kDa}$. Western blot analysis of tick $H$. excavatum crude adult extract with naturally infested cattle sera observed that there are reactions at three antigenic sites with 61.4, 47.3 , and $35 \mathrm{kDa}$, while their reaction with camel naturally infested sera showed two bands only at 117 and $61.4 \mathrm{kDa}$. This result demonstrates the cross-reactivity between $H$. dromedarii and $H$. excavatum (Figure-7).

\section{Discussion}

It is known that the ixodid ticks are vectors for many protozoan, bacterial, and viral pathogens. The capability of disease transmission differs from tick species to another. Most of the diseases transmitted by ticks do not restrict to animals but extend to humans [58]. In particular, bacterial diseases such as Rickettsia spp., Borrelia spp., and C. burnetii cause health problems for animals and humans $[59,60]$. Studies on C. burnetii (Q fever) in Egypt are limited, especially in camels and tick vectors. Therefore, the

Table-2: The prevalence of C. burnetii in camels and their ticks by PCR using IS30A spacer.

\begin{tabular}{|c|c|c|c|c|c|}
\hline \multirow[t]{2}{*}{ Governorates } & \multirow[t]{2}{*}{ Camels No. } & \multirow{2}{*}{$\begin{array}{c}\text { Positive number of camels } \\
\text { with } Q \text { fever (prevalence } \%) *\end{array}$} & \multicolumn{2}{|l|}{ Ticks } & \multirow{2}{*}{$\begin{array}{l}\text { Positive number of ticks with } \\
\text { Q fever (prevalence \%) }\end{array}$} \\
\hline & & & Species & No. & \\
\hline \multirow[t]{4}{*}{ Cairo } & 53 & $36(67.9)$ & H. dromedarii & 79 & 0 \\
\hline & & & H. excavatum & 4 & 0 \\
\hline & & & H. rufipes & 4 & 0 \\
\hline & & & H. marginatum & 2 & 0 \\
\hline \multirow[t]{2}{*}{ Giza } & 59 & $16(27.1)$ & H. dromedarii & 45 & $10(5.3)$ \\
\hline & & & H. excavatum & 1 & 0 \\
\hline \multirow[t]{2}{*}{ Sinai } & 1 & $0(0)$ & H. dromedarii & 53 & 0 \\
\hline & & & H. marginatum & 2 & 0 \\
\hline Total & 113 & $52(46.01)$ & Total & 190 & $10 / 190(5.3)$ \\
\hline
\end{tabular}

$* * \chi^{2}=7.692(\mathrm{p}=0.006) . H$. dromedarii=Hyalomma dromedarii, $H$. excavatum=Hyalomma excavatum, $H$. marginatum $=$ Hyalomma marginatum, $H$. rufipes $=$ Hyalomma rufipes, $C$. burnetii=Coxiella burnetii, $\mathrm{PCR}=\mathrm{Polymerase}$ chain reaction 


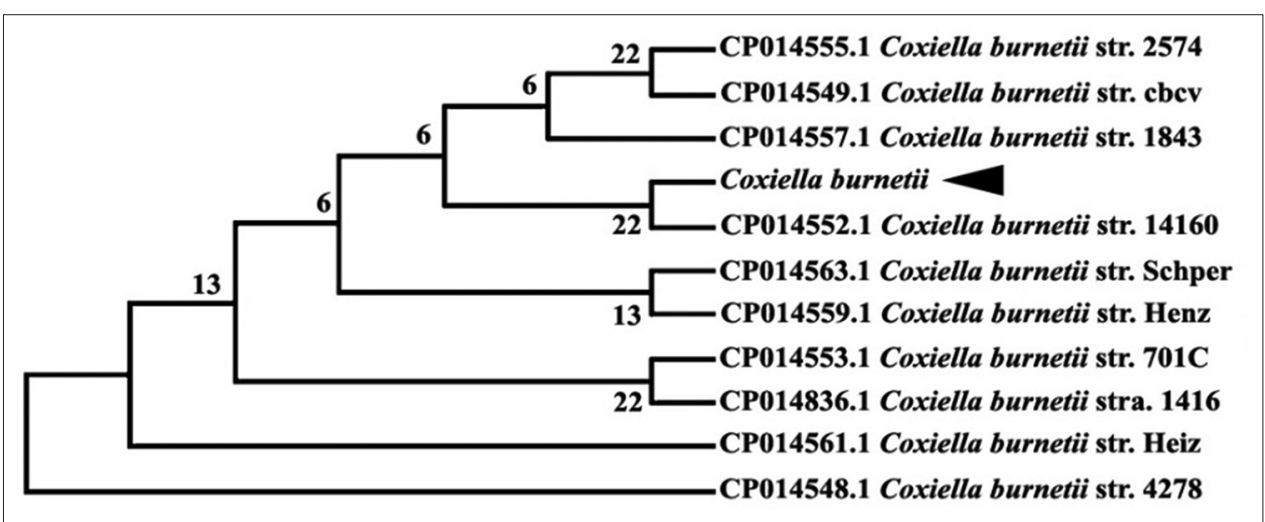

Figure-2: Phylogenetic tree of the IS30A sequences for Coxiella burnetii recorded in GenBank, including C. burnetii obtained from Hyalomma dromedarii in this study.

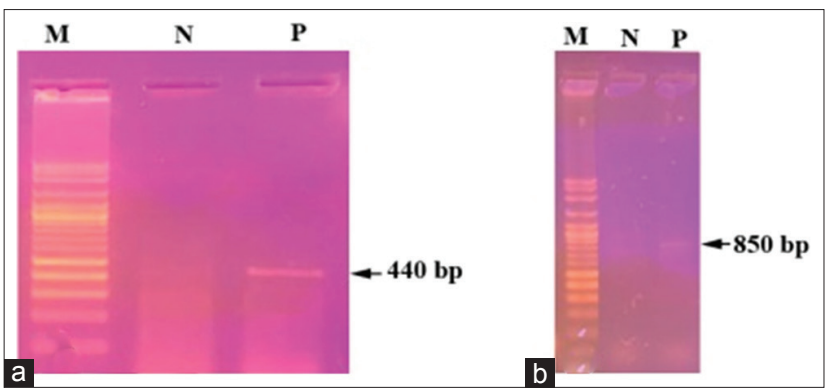

Figure-3: Agarose gel electrophoresis of polymerase chain reaction products obtained from Hyalomma dromedarii and Hyalomma excavatum using two genes: (a) $16 \mathrm{~S}$ ribosomal RNA gene reveals $440 \mathrm{bp}$, (b) cytochrome oxidase subunit-1 gene, reveals $850 \mathrm{bp}$, (M) 1 kb DNA ladder, (N) negative control.

first step of this study was conducted to investigate the presence of Q fever in camels and related ticks using PCR and sequencing analyses.

Furthermore, PCR and sequencing were used to achieve the second step that related to the examination of the two genes $16 \mathrm{~S}$ rRNA and $\mathrm{COI}$ for molecular characterization of the camel tick $H$. dromedarii and the tick $H$. excavatum. The selection of $16 \mathrm{~S}$ rRNA and CO1 genes was based on the previous studies $[25,45,46]$ whose stated that these DNA markers are more reliable in discriminating species of ticks. Whereas, the selection of $H$. dromedarii and $H$. excavatum for molecular studies is based on two reasons: (1) They have an economic important more than other tick species found on camels, wherever, $H$. dromedarii is the most dominant tick species, and $H$. excavatum has a wide range of animal hosts, and it can spread the disease from animal host to another through farm animals, and (2) the larval stages of these two tick species are very close to each other when they examined by scanning electron microscope by Abdel-Shafy [43]. The third step of this study is a trial to answer the following question using SDS-PAGE and western blot techniques. "Is it possible to identify an animal infested by $H$. dromedarii or H. excavatum serologically?"

Diagnosis of Q fever in camels in most previous publications was conducted by various serological methods. These studies indicated that the camels are a major reservoir of $C$. burnetii. The seroprevalence for Q fever revealed infection rates 7.9, 73, 19, 51.64, 28.26 , and $18.6 \%$ among camels investigated in United Arab Emirates, Chad, Spain, Saudi Arabia, Iran, and Kenya, respectively [61-66]. In Egypt, antibodies of C. burnetii was found in $13 \%$ and $70 \%$ of camel sera tested by ELISA $[14,67]$ and indirect immunofluorescence assay [68], respectively. Although molecular methods are more sensitive and specific for the diagnosis of the disease, little researches used these methods in the screening of Q fever in either camels or ticks. In general, the percentage of $C$. burnetii infection in camel blood or tick tissues detected by PCR was mostly lower than recorded by serological methods. The infection rate of $\mathrm{Q}$ fever detected in camels by PCR was $15.85 \%$ and $10.76 \%$ in Saudi Arabia and Iran, respectively [64,69]. In Spain, C. burnetii DNA was detected in 3.4 and $6.1 \%$ of ticks collected from animals at two different locations [70,71]. In Egypt, the present study is considered the first for molecular characterization of $\mathrm{Q}$ fever on either camels or ticks by PCR targeting the IS30A spacer. The results of this study revealed that 52 of 113 blood samples camels $(46 \%)$ were positive for $\mathrm{Q}$ fever infection. This percentage is higher than that recorded before in Saudi Arabia and Iran $[64,69]$. This may be due to the differences in environmental conditions between Egypt and these two geographical locations or the differences in the sensitivity of the genes used in PCR.

Furthermore, the results of the current study revealed that $10(5.3 \%)$ adult ticks of $H$. dromedarii were infected with $C$. burnetii using PCR. This low $\mathrm{Q}$ fever infection agrees with that recorded before in ticks collected from animals in Spain [70,71]. The band size of IS30A spacer of C. burnetii was $200 \mathrm{bp}$ in the positive samples of camel blood and tick tissues. The PCR products of $C$. burnetii DNA in camels failed to give sequences while in $H$. dromedarii ticks revealed good sequences with a similarity of $99 \%$ with that previously recorded in GenBank. This finding may attribute to the ticks had high C. burnetii DNA in comparing with a low density of DNA in the blood. 


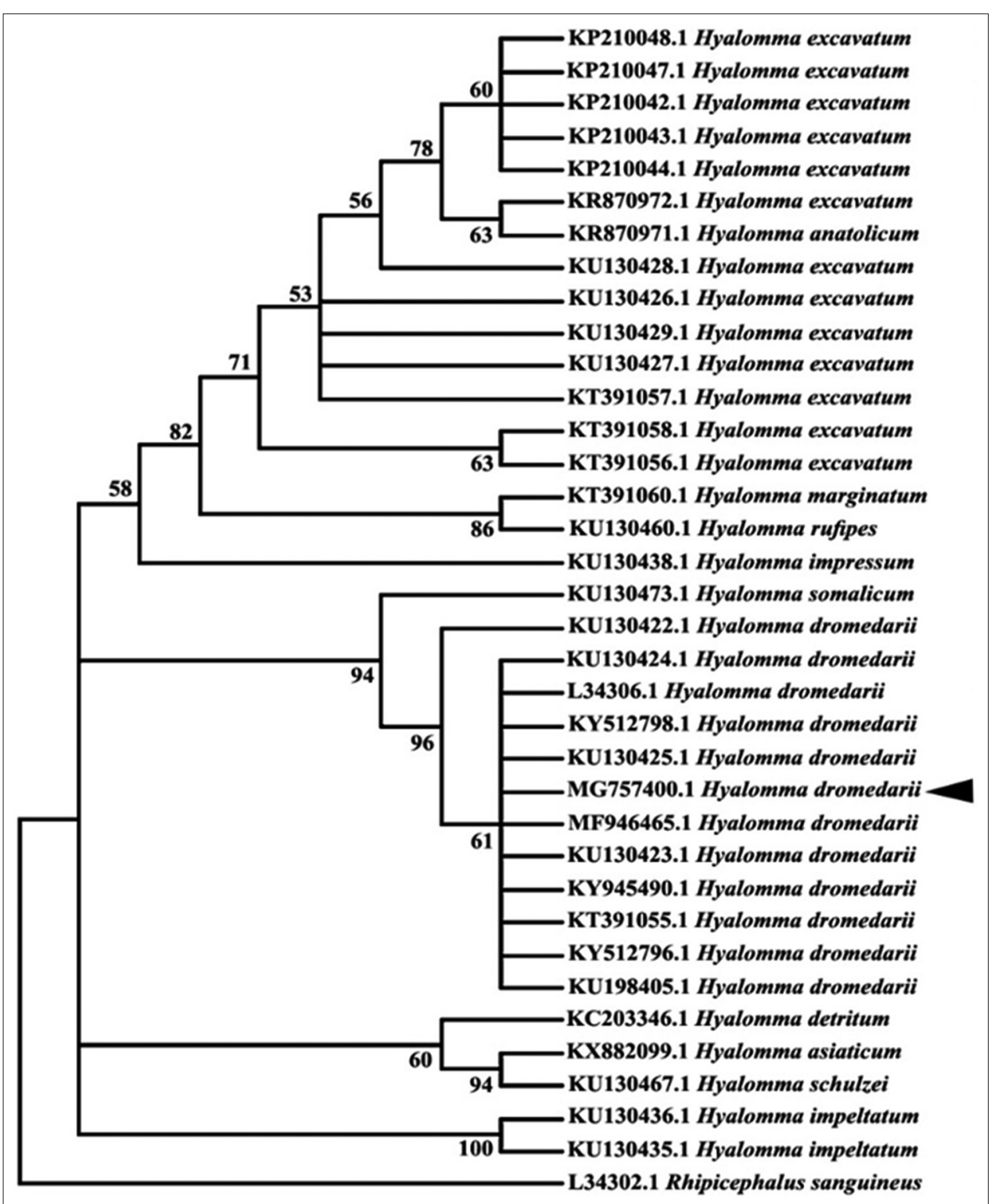

Figure-4: Phylogenetic tree of the 16S rDNA sequences for Hyalomma spp. recorded in GenBank, including Hyalomma dromedarii obtained in this study with accession number MG757400.

Meanwhile, the previous study indicated that Q fever was lower in blood and milk, but it is higher in faces and urine $[64,72]$. Then, this study confirms the presence of $C$. burnetii in $H$. dromedarii which can transmit from infected animals to healthy animals or humans directly by exposure to the infected ticks or by their offspring [73]. In contrary with Altay Çapin et al. [74] who found C. burnetii in H. excavatum, this tick species was found free from $\mathrm{Q}$ fever infection in the present study. This finding may attribute to the low number of $H$. excavatum ticks examined by PCR herein.

The taxonomists of ticks could easily identify tick species spread in their country, but they have misidentification rates when they identify tick species imported from other countries [75]. Nowadays, the molecular approach becomes an important trend in the taxonomic of tick species to resolve the misidentification problems. The most DNA markers used for molecular characterization of Hyalomma spp. are 18S
rRNA, second internal transcript spacer, 12S rDNA, CO1, 16S rDNA, and calreticulin [25,76-78]. In the present study, 16S rRNA and $\mathrm{CO} 1$ genes were chosen for molecular characterization of $H$. dromedarii and H. excavatum by PCR and sequence analysis based on the report of Lv et al. [46] who stated that 16S rRNA and $\mathrm{COl}$ genes are trustworthy in distinguishing species of ticks, while $18 \mathrm{~S}$ rRNA can distinguish ticks at the genera level. The results of this study showed that the PCR products of $16 \mathrm{~S}$ rRNA and $\mathrm{CO} 1$ genes revealed bands around 440 and $850 \mathrm{bp}$ in length, respectively, for both $H$. dromedarii and $H$. excavatum. Then, the sequencing is imperative to discriminate the two tick species. The gene 16S rRNA gave a good sequencing for $H$. dromedarii with $99 \%$ similarity with that recorded in GenBank. This sequence was recorded in GenBank and took number MG757400. However, the PCR products of 16S rRNA gene obtained from $H$. excavatum failed to give a good sequence despite it was repeated for many trials. This finding may be due 


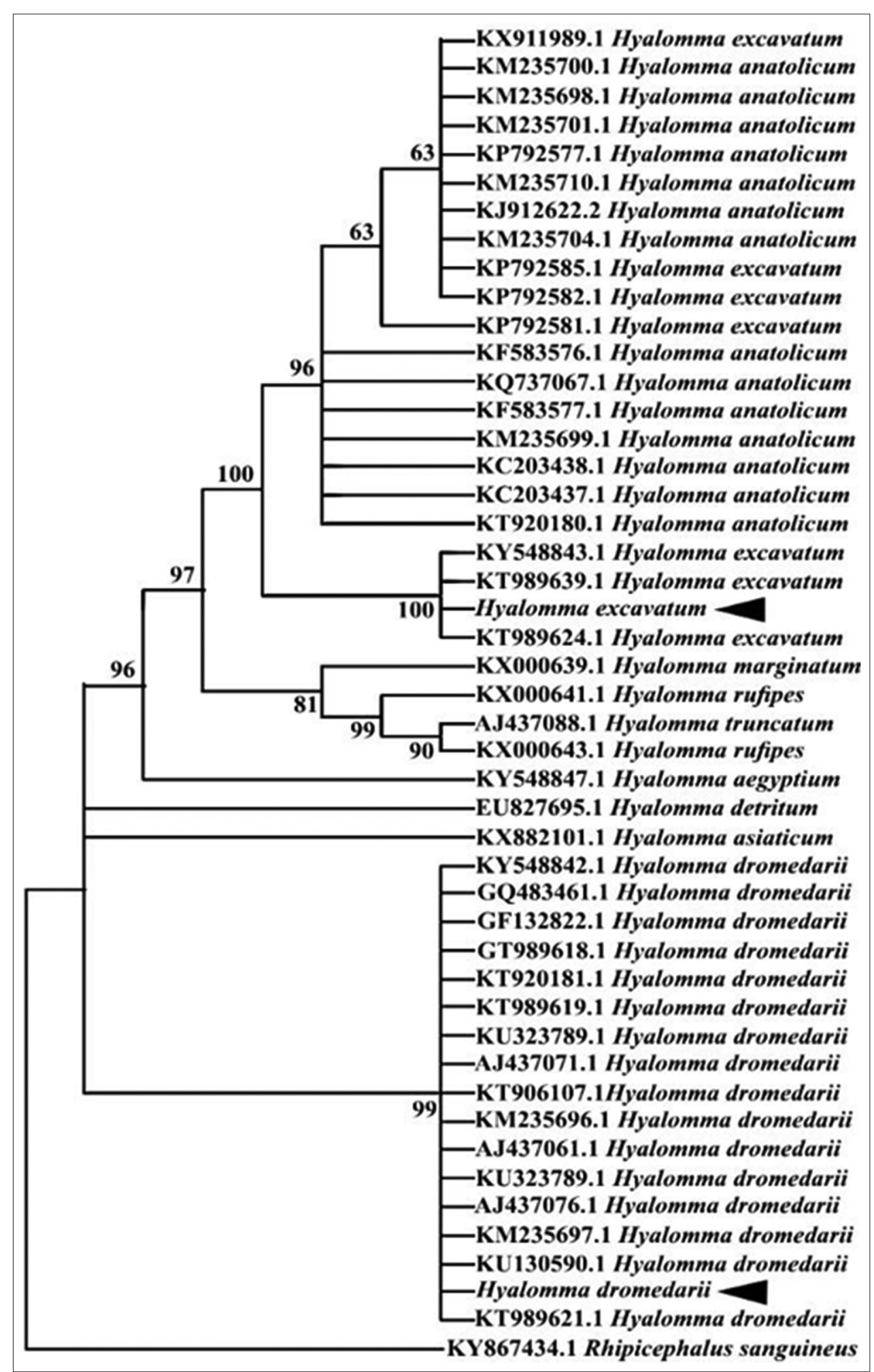

Figure-5: Phylogenetic tree of the cytochrome oxidase subunit-1 sequences for Hyalomma spp. recorded in GenBank, including Hyalomma dromedarii and Hyalomma excavatum obtained in this study.

to the 16S rRNA gene is not appropriate for $H$. excavatum tick, or there was a technical error occurred in preparing the sample for sequencing.

Furthermore, the present study added that the phylogenetic trees of 16S rRNA and COI genes for $H$. dromedarii confirmed that these species locate in the same glade with other $H$. dromedarii previously recorded in GenBank as well as the phylogenetic tree of $\mathrm{COl}$ gene for $H$. excavatum was also in a separate glade with others $H$. excavatum previously recorded in GenBank. These findings agree with the previous results that reported by Sands et al. [77] and Hekimoglu and Ozer [76] who found that each of $H$. dromedarii and $H$. excavatum locates in a separate clade when they analyzed phylogenetically. Then, this study confirms that the $\mathrm{COl}$ gene is used for 


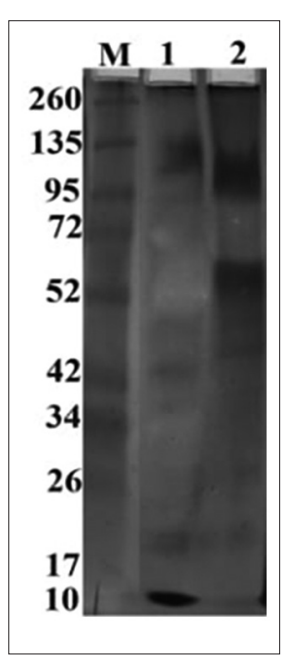

Figure-6: $10 \%$ sodium dodecyl sulfate-polyacrylamide gel electrophoresis of the isolated Hyalomma dromedarii and Hyalomma excavatum total adult crude proteins. Lane 2: whole $H$. dromedarii, Lane 3: $H$. excavatum. Tick protein bands were compared to ferment as wide range standards to estimate molecular weight.

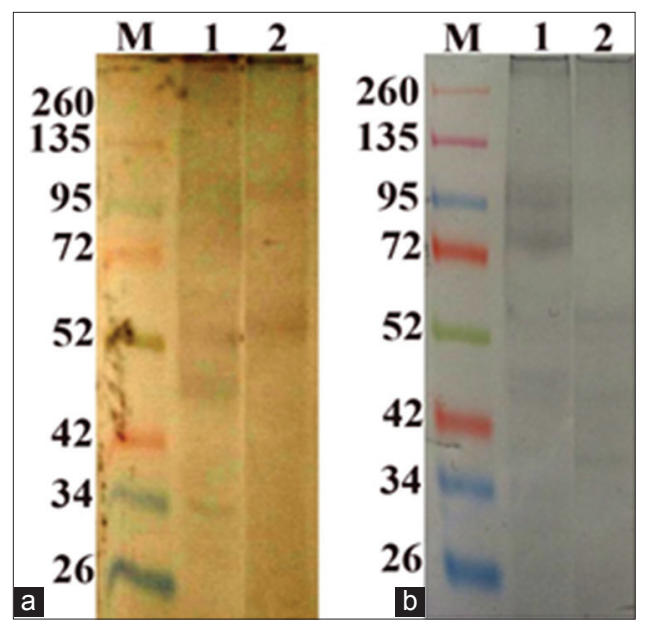

Figure-7: Immunoblot analysis of total protein adult crude extracts from different tick species. The samples from the following species were analyzed: (1) Hyalomma dromedarii and (2) Hyalomma excavatum. The blots were probed with camel sera naturally infested by $H$. dromedarii (a), and cattle sera naturally infested by $H$. excavatum (b). (M) ferment as wide range prestained molecular weight standard.

discrimination between $H$. dromedarii and $H$. excavatum, while 16S rRNA gene is suitable for $H$. dromedarii, but it needs additional trials for $H$. excavatum at least with the Egyptian strain of $H$. excavatum.

SDS-PAGE revealed seven bands for the adults of either $H$. dromedarii or $H$. excavatum with different molecular weights in each. Despite the protein profile in each tick species is different; we cannot depend on the protein profile alone in discriminating these tick species. Overlapping may occur between molecular weights of tick species in case of comparing the protein profiles of a large number of tick species. In western blot analyses, the sera obtained from either infested camel by $H$. dromedarii or infested cattle by $H$. excavatum revealed the same immunogenic bands $(100.7,49.7,43.9$, and $39.6 \mathrm{kDa})$ against $H$. dromedarii. However, the camel sera exhibited two immunogenic bands (117 and $61.4 \mathrm{kDa})$ against $H$. excavatum. Furthermore, the sera collected from cattle infested by $H$. excavatum revealed three immunogenic bands $(61.4,47.3$, and $35 \mathrm{kDa})$ against $H$. excavatum. It is thought that the cattle were infested by $H$. dromedarii because the cattle sera revealed the same immunogenic bands that recorded with camel sera. The difference between immunogenic bands for camel and cattle sera against $H$. excavatum may attribute to the camel was infested by other ixodid tick species besides $H$. dromedarii and stimulate the two immunogenic bands. The presence of the three immunogenic bands at $61.4,47.3$, and $35 \mathrm{kDa}$ in reaction of cattle sera with $H$. excavatum and their absence in reaction of camel sera against this tick species indicate to $H$. excavatum infestation in cattle and free $H$. excavatum infestation in camel. This means that it is possible to identify tick species through a serum obtained from an infested animal that has been infested by one tick species. To apply this conception, the sera must be obtained from an animal that has been infested experimentally to avoid cross-reactivity with other tick species in the natural field.

\section{Conclusion}

Molecular analyses indicated that both camels and ticks could be sources for the infection of animals and humans with Q fever. Furthermore, molecular analyses are more accurate tools for discriminating $H$. dromedarii and $H$. excavatum than immunological tools.

\section{Authors' Contributions}

HHAMA, EEE, SA, HAAA, and EHA participated in the design of the study. HHAMA and SA shared in collecting ticks and blood samples from camels. HHAMA, EEE, and SA participated in conducting PCR, sequences, and phylogenetic trees. EEE and EHA participated in antigen preparation and conducting SDS-PAGE and western blotting techniques. SA wrote the first draft of the manuscript. All authors reviewed and approved the final manuscript.

\section{Acknowledgments}

This work was financially supported by the National Research Centre, Giza, Egypt, as a part of a project No. 11020303 under the supervision of Prof. Dr. Hala A. A. Abou Zeina.

\section{Competing Interests} interests.

The authors declare that they have no competing

\section{References}

1. Chmielewski, T. and Tylewska-Weirzbanowska, S. (2012) Q fever at the turn of the century. Polish. J. Microbiol., 61: 81-93. 
2. Georgiev, M., Afonso, A., Neubauer, H., Needham, H., Thiéry, R., Rodolakis, A., Roest, H.J., Stärk, K.D., Stegeman, J.A., Vellema, P., van der Hoek, W. and More, S.J. (2013) Q fever in humans and farm animals in four European countries, 1982 to 2010. Euro. Surveill., 18: 20407.

3. Berri, M., Arricau-Bouvery, N. and Rodolakis, A. (2003) PCR-based detection of Coxiella burnetii from clinical samples. In: Sachse, K. and Frey, J., editors. Methods in Molecular Biology. Humana Press Inc., Totowa. p153-161.

4. Wernery, U. and Kaaden, O.R. (2002) Infectious Diseases of Camelids. Blackwell Science, Berlin.

5. Horton, K.C., Wasfy, M., Samaha, H., Abdel-Rahman, B., Safwat, S., Abdel Fadeel, M., Mohareb, E. and Dueger, E. (2014) Serosurvey for zoonotic viral and bacterial pathogens among slaughtered livestock in Egypt. Vector Borne Zoonotic Dis., 14: 633-639.

6. Guatteo, R., Seegers, H., Taurel, A.F., Joly, A. and Beaudeau, F. (2011) Prevalence of Coxiella burnetii infection in domestic ruminants: A critical review. Vet. Microbiol., 149: 1-16.

7. Fenollar, F., Fournier, P., Carrrieri, M.P., Habib, G., Messana, T. and Roult, D. (2001) Risk factors and prevention of Q fever endocarditis. Clin. Infect. Dis., 33: 312-316.

8. Hartzell, J.D., Wood-Morris, R.N., Martinez, L.J. and Trotta, R.F. (2008) Q fever: Epidemiology, diagnosis, and treatment. Mayo. Clin. Proc., 83: 574-579.

9. Weisburg, W.G., Dobson, M.E., Samuel, J.E., Dasch, G.A., Mallavia, L.P., Baca, O., Mandelco, L., Sechrest, J.E., Weiss, E. and Woese, C.R. (1989) Phylogenetic diversity of the Rickettsiae. J. Bacteriol., 171: 4202-4206.

10. Tan, C.K. and Owens, L. (2000) Infectivity, transmission and 16S rRNA sequencing of a Rickettsia, Coxiella cheraxi sp. nov., from the freshwater crayfish Cherax quadricarinatus. Dis. Aquat. Organ., 41: 115-122.

11. Duron, O., Jourdain, E. and McCoy, K.D. (2014) Diversity and global distribution of the Coxiella intracellular bacterium in seabird ticks. Ticks Tick Borne Dis., 5: 557-563.

12. Almeida, A.P., Marcili, A., Leite, R.C., Nieri-Bastos, F.A., Domingues, L.N., Ricardo Martins, J., Martins, J.R. and Labruna, M.B. (2012) Coxiella symbiont in the tick Ornithodoros rostratus (Acari: Argasidae). Ticks Tick Borne Dis., 3: 203-206.

13. Smith, T.A., Driscoll, T., Gillespie, J.J. and Raghavan, R.A. (2015) Coxiella-like endosymbiont is a potential vitamin source for the Lone Star Tick. Genome Biol. Evol., 7: 831-838.

14. Duron, O., Noël, V., McCoy, K.D., Bonazzi, M., SidiBoumedine, K., Morel, O., Vavre, F., Zenner, L., Jourdain, E., Durand, P., Arnathau, C., Renaud, F., Trape, J.F., Biguezoton, A.S., Cremaschi, J., Dietrich, M., Léger, E., Appelgren, A., Dupraz, M., Gómez-Díaz, E., Diatta, G., Dayo, G.K., Adakal, H., Zoungrana, S., Vial, L. and Chevillon, C. (2015) The recent evolution of a maternally-inherited endosymbiont of ticks led to the emergence of the Q fever pathogen, Coxiella burnetii. PLoS Pathog., 11: e1004892.

15. Madariaga, M.G., Rezai, K., Trenholme, G.M. and Weinstein, R.A. (2003) Q fever: A biological weapon in your backyard. Lancet Infect. Dis., 3: 709-721.

16. Bewley, K.R. (2013) Animal models of Q fever (Coxiella burnetii). Comp. Med., 63: 469-476.

17. van Schaik, E.J., Chen, C., Mertens, K., Weber, M.M. and Samuel, J.E. (2013) Molecular pathogenesis of the obligate intracellular bacterium Coxiella burnetii. Nat. Rev. Microbiol., 11: 561-573.

18. Cutler, S.J., Bouzid, M. and Cutler, R.R. (2007) Q fever. J. Infect., 54: 313-318.

19. Maurin, M. and Raoult D. (1999) Q fever. Clin. Microbiol. Rev., 12: 518-553.

20. Angelakis, E. and Raoult, D. (2010) Q- fever. Vet. Microbiol., 140: 297-309.
21. Mediannikov, O., Fenollar, F., Socolovschi, C., Diatta, G., Bassene, H., Molez, J.F., Sokhna, C., Trape, J.F. and Raoult, D. (2010) Coxiella burnetii in humans and ticks in rural Senegal. PLoS Negl. Trop. Dis., 4: e654.

22. Apanaskevich, D.A., Schuster, A.L. and Horak, I.G. (2008) The genus Hyalomma: VII. Redescription of all parasitic stages of $H$. (Euhyalomma) dromedarii and $H$. (E.) schulzei (Acari: Ixodidae). J. Med. Entomol., 45: 817-831.

23. Walker, A.R., Bouattour, A., Camicas, J.L., EstradaPena, A., Horak, I.G., Latif, A.A., Pegram, R.G. and Preston, P.M. (2003) Ticks of Domestic Animals in Africa: a Guide to Identification of Species. Bioscience Reports, Edinburgh, United Kingdom.

24. El Kammah, K.M., Oyoun, L.M., El Kady, G.A. and AbdelShafy, S.A. (2001) Investigation of blood parasites in livestock infested with argasid and ixodid ticks in Egypt. $J$. Egypt. Soci. Parasitol., 31: 365-371.

25. Abdullah, H.H.A.M., El-Molla, A., Salib, F.A., Allam, N.A.T., Ghazy, A.A. and Abdel-Shafy, S. (2016) Morphological and molecular identification of the brown dog tick Rhipicephalus sanguineus and the camel tick Hyalomma dromedarii (Acari: Ixodidae) vectors of Rickettsioses in Egypt. Vet. World, 9: 1087-1101.

26. Alsarraf, M., Mierzejewska, E.J., Mohallal, E.M.E., Behnke, J.M. and Bajer, A. (2017) Genetic and phylogenetic analysis of the ticks from the Sinai Massif, Egypt, and their possible role in the transmission of Babesia behnkei. Exp. Appl. Acarol., 72: 415-427.

27. Youssef, S.Y., Yasien, S., Mousa, W.M.A., Nasr, S.M., El-Kelesh, E.A.M., Mahran, K.M. and Abd-El-Rahman, A.H. (2015) Vector identification and clinical, hematological, biochemical, and parasitological characteristics of camel (Camelus dromedarius) theileriosis in Egypt. Trop. Anim. Health. Prod., 47: 649-656.

28. Hassan, M.I., Gabr, H.S.M., Abdel-Shafy, S., Hammad, K.M. and Mokhtar, M.M. (2017) Prevalence of tick-vectors of Theileria annulata infesting the one-humped camels in Giza, Egypt. J. Egypt. Soc. Parasitol., 47: 425-432.

29. Abdel-Shafy, S., Allam, N.A.T., Mediannikov, O., Parola, P. and Raoult, D. (2012) Molecular detection of spotted fever group Rickettsiae associated with ixodid ticks in Egypt. Vector Borne Zoonotic Dis., 12: 346-359.

30. Kleinerman, G., Baneth, G., Mumcuoglu, K.Y., Van Straten, M., Berlin, D., Apanaskevich, D.A., Abdeen, Z., Nasereddin, A. and Harrus, S. (2013) Molecular detection of Rickettsia africae, Rickettsia aeschlimannii, and Rickettsia sibirica mongolitimonae in camels and Hyalomma spp. ticks from Israel. Vector Borne Zoonotic Dis., 13: 851-856.

31. Ghoneim, N.H., Abdel-Moein, K.A. and Zaher, H.M. (2017) Molecular detection of Francisella spp. among ticks attached to camels in Egypt. Vector Borne Zoonotic Dis., 17: 384-387.

32. Loftis, A.D., Reeves, W.K., Szumlas, D.E., Abbassy, M.M., Helmy, I.M., Moririaty, J.R. and Dasch, G.A. (2006) Rickettsial agents in Egyptian ticks collected from domestic animals. Exp. Appl. Acarol., 40: 67-81.

33. Abdel-Shafy, S. and Allam, N.A.T. (2013) Quantitative real-time RT-PCR detection of flaviviruses associated with camel ticks in Egypt. Glob. Vet., 10: 394-402.

34. Hoogstraal, H. (1956) African Ixodoidea, Ticks of the Sudan. NAMRU-3, Cairo, Egypt. p1101.

35. Apanaskevich, D.A. (2004) Host-parasite relationships of the genus Hyalomma Koch, 1844 (Acari, Ixodidae) and their connection with microevolutionary process. Parazitologiya, 38: $515-523$

36. Estrada-Pena, A., Bouattour, A., Camicas, J.L. and Walker, A.R. (2004) Ticks of Domestic Animals in the Mediterranean Region. A guide to Identification of Species. $1^{\text {st }}$ ed. p131.

37. Friedhoff, K.T. (1997) Tick-borne diseases of sheep and goats caused by Babesia, Theileria or Anaplasma spp. Parasitologia, 39: 99-109. 
38. Sayin, F., Karaer, Z., Dincer, S., Cakmak, A., Inci, A., Yukabi, B.A., Eren, H., Vatansever, Z., Nalbantoglu, S. and Melrose, T.R. (2003) A comparison of susceptibilities to infection of four species of Hyalomma ticks with Theileria annulata. Vet. Parasitol., 113: 115-121.

39. Aktas, M., Dumanli, N. and Angin, M., (2004) Cattle infestation by Hyalomma ticks and prevalence of Theileria in Hyalomma species in the East of Turkey. Vet. Parasitol. 119: 1-8.

40. Khan, A.S., Maupin, G.O., Rollin, P.E., Noor, A.M., Shurie, H.H.M., Shalabi, A.G.A., Wasef, S., Haddad, Y.M.A., Sadek, R., Ijaz, K., Peters, C.J. and Ksiazek, T.G. (1997) An outbreak of Crimean-Congo hemorrhagic fever in the United Arab Emirates, 1994-1995. Amer. J. Trap. Med. Hyg., 57: 519-525.

41. Caporale, D.A., Rich, S.M., Spielman, A., Telford, S.R. and Kocher, T.D. (1995) Discriminating between Ixodes ticks by means of mitochondrial DNA sequences. Mol. Phylogenet. Evol., 4: 361-365.

42. Guglielmone, A.A., Venzal, J.M., Gonzáleh, Z., Acuña, D., Nava, S., Hinojosa, A. and Mangold, A.J. (2006) The phylogenetic position of Ixodes stilesi Neumann 1911 (Acari: Ixodidae): Morphological and preliminary molecular evidences from 16S rDNA sequences. Syst. Parasitol., 65: $1-11$.

43. Abdel-Shafy, S. (2008) Scanning electron microscopy and comparative morphology of Hyalomma anatolicum excavatum, $H$. dromedarii and $H$. marginatum (Acari: Ixodidae) based on larvae. Acarologia, 48: 127-139.

44. Zilberman, N., Reikhav, S., Hulata, G. and Ron, M. (2006) High-throughput genomic DNA extraction protocol from Tilapia Fine Tissue. Aquacult., 255: 597-599.

45. Chitimia, L., Lin, R., Cosoroaba, I., Wu, X., Song, H., Yuan, Z. and Zhu, X. (2010) Genetic characterization of ticks from southwestern Romania by sequences of mitochondrial cox1 and nad5 genes. Exp. Appl. Acarol., 52: 305-311

46. Lv, J., Wu, S., Zhang, Y., Zhang, T., Feng, C., Jia, G. and Lin, X. (2014) Development of a DNA barcoding system for the Ixodida (Acari: Ixodida). Mitochond. DNA, 25: 142-149.

47. Dessen, P., Fondrat, C., Valencien, C. and Bisance, A. (1990) A French service for access to biomolecular databases. CABIOS, 6: 355-356.

48. Saitou, N. and Nei, M. (1987) The neighbor-joining method: A new method for sequences. J. Mol. Biol., 16: 111-120.

49. Dawyndt, P., Demeyer, H. and De Baets, B. (2006) UPGMA clustering revisited: A weight-driven approach to transitive approximation. Inter. J. Appr. Reas., 42: 174-191.

50. Tamura, K., Nei, M. and Kumar, S. (2004) Prospects for inferring very large phylogenies by using the neighbor-joining method. Proc. Natl. Acad. Sci. USA., 101: 11030-11035.

51. Felsenstein, J. (1985) Confidence limits on phylogenies: An approach using the bootstrap. Evolution., 39: 783-791.

52. Felsenstein, J. (2004) Inferring Phylogenies. 1. Sinauer Associates Inc., Sunderland, MA.

53. Tamura, K., Dudley, J., Nei, M. and Kumar, S. (2007) MEGA4: Molecular evolutionary genetics analysis (MEGA) software version 4.0. Mol. Biol. Evol., 24: 1596-1599.

54. Lowry, O.H., Rosenbrough, N.J., Farr, A.L. and Randael, R.J. (1951) Protein measurement with the folin phenol reagent. J. Biologic. Chemist., 193: 265-275.

55. Laemmli, U.K. (1970) Cleavage of structural proteins during the assembly of the head of bacteriophage T4. Nature, 227: 680-685.

56. Wray, W., Boulikas, T., Wray, V.P. and Hancock, R. (1981) Silver staining of proteins in polyacrylamide gels. Anal. Biochem., 118: 197-203.

57. Towbin, H., Stachelin, T. and Gordon, J. (1979) Electrophoretic transfer of proteins from polyacrylamide gels to nitrocellulose sheets: Procedure and some applications. Proc. Nat. Acad. Sci. USA, 176: 4350-4354.
58. Dantas-Torres, F., Chomel, B.B. and Otranto, D. (2012) Ticks and tick-borne diseases: A one health perspective. TREPAR, 1138: 1-10.

59. Parola, P., Paddock, D.C., Socolovschi, C., Labruna, B.M., Mediannikov, O., Kernif, T., Abdad, Y.M., Stenos, J., Bitam, I., Fournier, P. and Raoult, D. (2013) Update on tick-borne rickettsioses around the world: A geographic approach. Clin. Microbiol. Rev., 26: 657-702.

60. Eldin, C., Melenotte, C., Mediannikov, O., Ghigo, E., Million, M., Edouard, S., Mege, J., Maurin, M. and Raoult, D. (2017) From Q Fever to Coxiella burnetii infection: A paradigm change. Clin. Microbiol. Rev., 30: 115-190.

61. Schelling, E., Diguimbaye, C., Daoud, S., Nicolet, J. and Zinsstag, J. (2004) Seroprevalences of zoonotic diseases in nomads and their livestock in Chari-Baguirmi, Chad. Médecine tropicale: revue du Corps de santé colonial, 64: 474-477.

62. Afzal, M. and Sakkir, M. (1994) Survey of antibodies against various infectious disease agents in racing camels in Abu Dhabi, United Arab Emirates. OIE Revue Scientifique et Technique, 13: 787-792.

63. Mentaberre, G., Gutiérrez, C., Rodríguez, N.F., Joseph, S., González-Barrio, D., Cabezón, O., de la Fuente, J., Gortazar, C. and Boadella, M. (2013) A transversal study on antibodies against selected pathogens in dromedary camels in the Canary Islands, Spain. Vet. Microbiol., 167: 468-473.

64. Hussein, M.F., Alshaikh, M.A., Al-Jumaah, R.S., GarelNabi, A., Al-Khalifa, I. and Mohammed, O.B. (2015) The Arabian camel (Camelus dromedarius) as a major reservoir of Q fever in Saudi Arabia. Comp. Clin. Path., 24: 887-892.

65. Mohabbati, M.A., Bagheri, A.F. and Esmaeili, S. (2017) Seroprevalence of Q fever among human and animal in Iran; A systematic review and meta-analysis. PLoS Negl. Trop. Dis., 11(4): e0005521.

66. Browne, A.S., Fèvre, E.M., Kinnaird, M., Muloi, D.M., Wang, C.A., Larsen, P.S., O'Brien, T. and Deem, S.L. (2017) Serosurvey of Coxiella burnetii (Q fever) in Dromedary Camels (Camelus dromedarius) in Laikipia County, Kenya. Zoonoses Public Health, 64: 543-549.

67. Soliman, A.K., Botros, B.A.M. and Watts, D.M. (1992) Evaluation of a competitive enzyme immunoassay for detection of Coxiella burnetii antibody in animal sera. J. Clin. Microbiol., 30: 1595-1597.

68. Mazyad, S.A. and Hafez, A.O. (2007) Q fever (Coxiella burnetii) among man and farm animals in North Sinai, Egypt. J. Egypt. Soc. Parasitol., 37: 135-142.

69. Doosti, A., Arshi, A. and Sadeghi, M. (2014) Investigation of Coxiella burnetii in Iranian camels. Comp. Clin. Path., 23: 43-46.

70. Toledo, A., Jado, I., Olmeda, A.S., Casado-Nistal, M.A., Gil, H., Escudero, R. and Anda P. (2009) Detection of Coxiella burnetii in ticks collected from central Spain. Vector Borne Zoonotic Dis., 9: 465-468.

71. Bolaños-Rivero, M., Carranza-Rodríguez, C., Rodríguez, N.F., Gutiérrez, C. and Pérez-Arellano, J.L. (2017) Detection of Coxiella burnetii DNA in peridomestic and wild animals and ticks in an endemic region (Canary Islands, Spain. Vector Borne Zoonotic Dis., 17: 630-634.

72. Mohammed, O.B., Jarelnabi, A.A., Aljumaah, R.S., Alshaikh, M.A., Bakhiet, A.O., Omer, S.A., Alagaili, A.N. and Hussein, M.F. (2014) Coxiella burnetii, the causative agent of Q fever in Saudi Arabia: Molecular detection from camel and other domestic livestock. Asian Pac. J. Trop. Med., 7: 715-719.

73. Široký, P., Kubelová, M., Modrý, D., Erhart, J., Literák, I., Špitalská, E. and Kocianová, E. (2010) Tortoise tick Hyalomma aegyptium as long-term carrier of $\mathrm{Q}$ fever agent Coxiella burnetii-evidence from experimental infection. Parasitol. Res., 107: 1515-1520.

74. Altay, Ç.G., Emre, Z., Canpolat, S., Vatansever, Y. and Düzgün, A. (2013) Detection of Coxiella burnetii from 
ticks by polymerase chain reaction and restriction fragment length polymorphism. Ankara Universitesi Veteriner Fakultesi Dergisi, 60(4), 263-268.

75. Estrada-Peña, A., D’Amico, G., Palomar, A.M., Dupraz, M., Fonville, M., Heylen, D., Habela, M.A., Hornok, S., Lempereur, L., Madder, M., Núncio, M.S., Otranto, D., Pfaffle, M., Plantard, O., Santos-Silva, M.M., Sprong, H., Vatansever, Z., Vial, L. and Mihalca, A.D. (2017) A comparative test of ixodid tick identification by a network of European researchers. Ticks Tick Borne Dis., 8: 540-546.

76. Hekimoglu, O. and Ozer, A.N. (2017) Distribution and phylogeny of Hyalomma ticks (Acari: Ixodidae) in Turkey. Exp. Appl. Acarol., 73: 501-519.
77. Sands, A.F., Apanaskevich, D.A., Matthee, S., Horak, I.G., Harrison, A., Karim, S., Mohammad, M.K., Mumcuoglu, K.Y., Rajakaruna, R.S., Santos-Silva, M.M. and Matthee, C.A. (2017) Effects of tectonics and largescale climatic changes on the evolutionary history of Hyalomma ticks. Mol. Phylogenet. Evol., 114: 153-165.

78. Sivakumar, G., Swami, S.K., Nagarajan, G., Mehta, S.C., Tuteja, F.C., Ashraf, M. and Patil, N.V. (2018) Molecular characterization of Hyalomma dromedarii from North Western Region of India based on the gene sequences encoding calreticulin and internally transcribed spacer region 2. Gene Reports, 10: 141-148.

$* * * * * * * *$ 